\title{
FAKTOR YANG MEMPENGARUHI DAYA TARIK WISATAWAN DALAM PENGEMBANGAN PARIWISATA BAHARI DI PANTAI TANJUNG BENOA
}

\author{
Ni Luh Kardini ${ }^{1}$ \\ Ni Wayan Ari Sudiartini² \\ Program Studi Manajemen, Fakultas Ekonomi, \\ Universitas Mahendradatta Bali \\ Jl. Ken Arok No. 12 Peguyangan Denpasar Utara, Bali 80115
}

\begin{abstract}
Abstrak
Wisata bahari termasuk wisata laut, danau, dan sungai. Kawasan bahari merupakan kawasan yang tidak dapat dipisahkan dari wilayah kelautan, di Indonesia sebagian besar kawasan wisatanya yaitu wisata bahari yang didalamnya terdapat pantai yang menjadi salah satu daya tarik wisata alam dan banyak diminati oleh wisatawan. Untuk mengetahui faktor yang mempengaruhi daya tarik wisata dalam pengembangan pariwisata bahari di pantai tanjung benoa dan cara meningkatkan daya tarik wisata dalam pengembangan pariwisata bahari serta mengetahui keamanan sarana dan prasarana di obyek wisata pantai tanjung benoa.

Kata Kunci : Wisata Bahari, Tanjung Benoa, Objek Wisata

Abstract

Marine tourism includes sea, lake and river tourism. The maritime area is an area that cannot be separated from the maritime area, in Indonesia most of the tourist areas are marine tourism in which there is a beach which is one of the attractions of natural tourism and much sought after by tourists. To find out the factors that influence the attractiveness of tourism in the development of marine tourism on the coast of Tanjung Benoa and how to increase the attractiveness of tourism in the development of marine tourism and to know the safety of facilities and infrastructure in Tanjung Benoa beach tourism.
\end{abstract}

Keywords: Marine Tourism, Tanjung Benoa, Tourism Objects 


\section{PENDAHULUAN}

Pariwisata merupakan industri yang produknya dinikmati di tempat dimana wisatawan itu berada. Produk pariwisata adalah sesuatu yang dapat dilihat, dilakukan, dibeli, dinikmati, dan diikuti. Kegiatan pada sektor pariwisata telah berkembang sejala dengan perkembangan-perkembangan yang telah ada baik dari sosial, ekonomi, pendidikan, serta alat transportasi yang semakin maju. Hal ini juga menjadi pelung besar bagi pengusaha bisnis untuk menggali dan memanfaatkan potensi yang ada, pariwisata juga berperan besar dalam peningkatan devisa negara dan kesejahteraan masyarakat sekitar sehingga pada zaman sekarang Pemerintah dan Pemerintah Daerah sudah mulai ikut serta dalam pengembangan pariwisata itu sendiri. Pada hakikatnya berpariwisata adalah suatu proses kepergian sementara seseorang menuju tempat lain untuk mendapatkan kenikmatan maupun memenuhi hasrat ingin mengetahui sesuatu. Indonesia merupakan negara maritim yang memiliki keanekaragaman flora dan fauna, peninggalan purbakala, peninggalan sejarah, serta seni dan budaya yang dapat dimanfaatkan secara optimal melalui penyelenggaraan pariwisata. Indonesia juga terkenal dengan sebutan negara maritim karena sebagian besar wilayahnya merupakan lautan luas. Potensi keanekaragaman tersebut bernilai tinggi dalam pengembangan pariwisata yang semakin banyak diminat wisatawan khususnya minat terhadap wisata bahari.

Wisata bahari termasuk wisata laut, danau, dan sungai. Kawasan bahari merupakan kawasan yang tidak dapat dipisahkan dari wilayah kelautan, di Indonesia sebagian besar kawasan wisatanya yaitu wisata bahari yang didalamnya terdapat pantai yang menjadi salah satu daya tarik wisata alam dan banyak diminati oleh wisatawan. Menurut Bengen (2001), menjadi Negara kepulauan terbesar di dunia yang memiliki 17.508 pulau dengan panjang garis pantai $81.000 \mathrm{~km}$, sehingga hal tersebut mampu mengidentifikasikan bahwa Indonesia memiliki potensi sumber daya pesisir dan lautan yang sangat besar. Jeni wisata ini erat kaitannya dengan aktivitas seperti berjemur dibawah seinar matahari, berenang, aktivitas olahraga air, mengumpulkan kerangka maupun berfoto dikarenakan wisata bahari merupakan wujud pemanfaatan secara optimal terhadap potensi kelautan.

Begitu lahnya dengan pulai Bali, Pulau Bali selalu menjadi pilihan tempat berlibur oleh para wisatawan baik domestik maupun mancanegara. Bali adalah primadona pariwisata Indonesia yang sudah terkenal di seluruh dunia. Selain terkenal dengan keindahan alam, terutama pantainya, Bali juga terkenal dengan kesenian dan budayanya yang unik dan menarik. Industri pariwisata berpusat di Bali Selatan dan di beberapa daerah lainnya. Lokasi wisata yang utama adalah Kuta dan sekitarnya seperti Legian dan Seminyak, daerah timur kota seperti Sanur, pusat kota seperti Ubud, dan di daerah selatan seperti Jimbaran, Nusa Dua dan Pecatu. Bali sebagai tempat tujuan wisata yang lengkap dan terpadu memiliki banyak sekali tempat wisata menarik, antara lain : Pantai Kuta, 
Pura Tanah Lot, Pantai Padang - Padang, Danau Beratan Bedugul, Garuda Wisnu Kencana (GWK), Pantai Lovina dengan Lumba Lumbanya, Pura Besakih, Uluwatu, Ubud, Munduk, Kintamani, Amed, Tulamben, Pulau Menjangan dan masih banyak yang lainnya. Kini, Bali juga memiliki beberapa pusat wisata yang sarat edukasi untuk anak-anak seperti kebun binatang, museum tiga dimensi, taman bermain air, dan tempat penangkaran kura-kura. Pulau Bali terletak di sebelah timur Pulau Jawa dan sebelah barat Pulau Lombok. Jarak dengan ujung tertimur Pulau Jawa yaitu $1,6 \mathrm{~km}$. Titik tertinggi pulau ini yaitu Gunung Agung dengan tinggi 3.142 meter. Keindahan pantai yang dimiliki oleh pulau bali menjadi salah satu daya tarik bagi para wisatawan. Banyak wisatawan datang ke Bali untuk dapat mengunjungi pantai - pantai yang ada di bali dan menikmati keindahan serta obyek - obyek wisata bahari yang ada di pantai. Salah satu tempat wisata di bali yag terkenal dengan wisata baharinya yaitu pantai tanung benoa. Obyek wisata pantai Tanjung Benoa Bali yang terletak di daerah tanjung benoa menjadi salah satu kawasan wisata bahari favorit para wisatawan. Banyak hal - hal menarik yang disuguhkan oleh Pantai Tanjung Benoa. Dimana obyek wisata Tanjung Benoa merupakan pusat wisata bahari di Bali atau lebih dikenal dengan nama watersport Tanjung Benoa dan memiliki pasir putih dengan air laut yang tenang serta keindahan bawah lautnya. Lokasi dari tempat wisata Tanjung Benoa Bali, berada di ujung tenggara pulau Bali. Tanjung Benoa merupakan sebuah kelurahan yang masuk dalam kecamatan
Kuta Selatan. Perjalanan menuju Pantai Tanjung Benoa jika datang dari airport Ngurah Rai, anda hanya memerlukan waktu 30 menit untuk sampai di Tanjung Benoa tempat wisata Bali. Tentunya durasi tempuh dari bandara ke Tanjung Benoa sekitar 30 menit jika tidak ada kemacetan di jalan raya. Kemacetan akan sangat sering anda lihat di jalan raya menuju objek wisata jika anda sedang berlibur pada saat musim ramai di Bali. Musim ramai di Bali pada bulan Juli, Agustus, Desember dan Awal Januari. Hampir setiap hari tempat wisata Tanjung Benoa Bali, tidak pernah sepi akan kunjungan wisatawan, baik wisatawan domestik maupun wisatawan mancanegara. Walaupun ada banyak lokasi aktivitas wisata bahari di pulau Bali, namun Tanjung Benoa watersports selalu menjadi idola wisatawan. Hal ini diakibatkan karena tersedia banyak pilihan permainan serta harga wahana sangat murah. Tidak hanya water sport, wahana permainan lainnya yang tersedia seperti parasailing, jet ski, banana boat, fly fish, snorkeling dan wisata ke pulau penyu. Selain pantai pasir putih dan aktivitas wisata bahari, Tanjung Benoa memiliki sarana parasarana pariwisata yang sangat lengkap. Seperti tersedia banyak pilihan hotel dari harga murah sampai hotel mewah, tersedia restoran, dan banyak pilihan untuk aktivitas SPA.

Pantai Tanjung Benoa saat ini menjadi suatu kawasan wisata bahari yang banyak diminati boleh wisatawan nusantara, pantai ini memiliki potensi untuk terus dikembangkan sebagai kawasan wisata bahari. Agar suatu kawasan wisata dapat dijadikan sebagai salah satu obyek wisata yang menarik 
dengan menyediakan atraksi wisata yang beragam yang dapat dinikmati oleh para wisatawan. Hal tersebut merupakan suatu usaha dalam menciptakan kawasan wisata bahari yang unik juga dapat mendatangkan wisatawan lebih banyak lagi dan bagi para wisatawan yang sudah pernah berkunjung menimbulkan keinginan untuk kembali berkunjung. Dikenalnya suatu obyek wisata tidak terlepas dari berbagai keunikan yang dimiliki, dengan memperhatikan dan berusaha untuk mengembangkan keunikan yang dimiliki tersebut diharapkan dapat memberikan dampat yang positif terhadap kemajuan dari wisata tajung benoa. Hal tersebut dapat dilakukan dengan melihat faktor - faktor apa saya yang dapat mempengaruhi daya tarik wisata di pantai tanjung benoa. Pengembangan dalam sebuah obyek wisata sangat penting untuk dilakukan, terutama untuk dapat memberikan kepuasan bagi para wisatawan yang datang. Sebagai tempat wisata yang terkenal dengan wisata baharinya, pengelola pantai tanjung benoa juga harus mengetahui bagaimana cara untuk meningkatkan daya tarik pariwisata baharinya. Untuk menarik para wisatawan tidak bisa dengan terus mengandalkan keunikan serta obyek wisata yang sudah ada tanpa ada pengembangan dan peningkatan yang berbeda dari obyek -obyek wisatanya. Oleh karena itu perlu adanya peningkatan daya tarik wisata terutama pariwisata bahari yang ditawarkan. Untuk kemjuan tempat wisata tanjung benoa, tidak hanya kemajuan dari obyek wisata saja yang harus diperhatikan tetapi sarana dan prasaran wisata bahari juga perluan untuk diperhatikan. Wahana - wahana permainan yang ditawarkan di pantai tanjung benoa merupakan wahana permainan yang memerlukan perhatian yang khusus. Seperti wahana parasailing, jet ski, banana boat, fly fish, snorkeling. Memberikan perhatian yang khusus sangat penting bagi permainan yang memacu adrenalin dan meliliki risiki tinggi. Dengan adanya sarana dan prasarana yang terjamin memberikan rasa nyaman dan keamanan bagi para wisatawan, sehingga dapat memberikan rasa puas dan menumbuhkan rasa percaya terhadap obyek wisata yang kita tawarkan. Melihat besarnya potensi yang terdapat dalam wisata bahari makan kami membuat sebuah peper yang berjudul tentang "Faktor Yang Mempengaruhi Daya Tarik Wisata Dalam Pengembangan Pariwisata Bahari Di Pantai Tanjung Benoa".

\section{Rumusan Masalah}

1. Apa faktor yang mempengaruhi daya tarik wisata dalam pengembangan pariwisata bahari di Pantai Tanjung Benoa?

2. Bagaimana cara meningkatkan daya tarik pariwisata Bahari di Pantai Tanjung Benoa?

3. Apa yang bisa terjadi jika saran dan prasarana di obyek wisata Tanjung Benoa tidak terjaga dengan baik?

\section{Manfaat Penulisan}

Dapat mengetahui faktor dan cara meningkatkan daya tarik wisata dalam pengembangan pariwisata bahari serta mengetahui keamanan sarana dan prasarana di obyek wisata pantai tanjung benoa.

\section{Tujuan Penulisan}


1. Untuk mengetahu apa saja faktor yang mempengaruhi daya tarik wisata dalam pengembangan pariwisata bahari di pantai tanjung benoa.

2. Untuk mengetahui bagaimana cara meningkatkan daya tarik pariwisata bahari di pantai tanjung benoa.

3. Untuk mengetaui sarana dan prasarana yang ada di obyek wisata tanung benoa.

\section{KAJIAN LITERATUR \\ Pariwisata}

Menurut Undang-Undang Nomor 10 Tahun 2009 tentang Kepariwisataan, pariwisata adalah berbagai macam kegiatan wisata yang didukung oleh berbagai fasilitas serta layanan yang disediakan masyarakat, pengusaha, Pemerintah, dan Pemerintah Daerah.

Berikut adalah pengertian pariwisata menurut beberapa ahli:

1. Menurut Robert McIntosh, pariwisata adalah gabungan dari interaksi antara pemerintah selaku tuan rumah pariwisata, bisnis, dan wisatawan.

2. Menurut Herman V. Schulard, pariwisata adalah sejumlah kegiatan terutama yang ada kaitannya dengan perekonomian secara langsung berhubungan dengan masuknya orang-orang asing melalui jalur lalu lintas di suatu negara, kota, dan daerah tertentu.

3. Menurut Prof. Salah Wahab, pariwisata adalah suatu aktivitas manusia yang dilakukan secara sadar dan mendapat pelayanan secara bergantian di antara orangorang dalam suatu negara itu sendiri ataupun di luar negeri, meliputi pendiaman orang-orang dari daerah lain untuk sementara waktu dalam mencari dan memperoleh kepuasan yang beraneka ragam dan berbeda dengan apa yang dialaminya (dimana ia tinggal).

Dewasa ini perjalanan wisata tidak hanya dilakukan untuk rekreasi atau liburan saja tapi juga bisa dilakukan untuk mencari pengalaman baru serta melihat keanekaragaman adat dan istiadat yang ada disuatu daerah. Dalam tujuan dan maksud perjalana wisata, ada beberapa jenis pariwisata yang dapat dilakukan, antara lain yaitu:

1. Wisata Budaya

Ini dimaksudkan agar perjalanan yang dilakukan atas dasar keinginan, untuk memperluas pandangan hidup seseorang dengan jalan mengadakan kunjungan atau peninjauan ketempat lain atau ke luar negeri, mempelajari keadaan rakyat, kebiasaan dan adat istiadat, cara hidup, budaya dan seni pada masyarakat daerah yang bersangkutan. Seringnya perjalanan serupa ini disatukan dengan kesempatan-kesempatan mengambil bagian dalam kegiatan-kegiatan budaya, seperti eksposisi seni (seni tari, seni drama, seni musik dan seni suara), atau kegiatan yang bermotif kesejarahan dan sebagainya. Jenis wisata budaya ini jenis yang populer di Indonesia. Jenis wisata ini adalah jenis wisata yang paling utama bagi wisatawan luar negeri yang datang ke 
negeri ini dimana mereka ingin mengetahui kebudayaan kita, kesenian dan segala sesuatu yang dihubungkan dengan adat istiadat dan kehidupan seni budaya kita.

2. Wisata Kesehatan

$$
\begin{aligned}
& \text { Hal ini dimaksudkan } \\
& \text { perjalanan seorang wisatawan } \\
& \text { dengan tujuan untuk menukar } \\
& \text { keadaan dan lingkungan tempat } \\
& \text { sehari-hari dimana ia tinggal demi } \\
& \text { kepentingan beristirahat alam arti } \\
& \text { jasmani an rohani, dengan } \\
& \text { mengunjungi tempat peristirahatan } \\
& \text { seperti mata air panas yang } \\
& \text { mengandung mineral yang dapat } \\
& \text { menyembuhkan, tempat yang } \\
& \text { mempunyai iklim udara yang } \\
& \text { mneyehatkan atau tempat-tempat } \\
& \text { yang menyediakan fasilitas-fasilitas } \\
& \text { kesehatan lainnya. }
\end{aligned}
$$

3. Wisata Olahraga

Ini dimasudkan wisatawan yang melakukan perjalanan dengan tujuan berolahraga atau memang sengaja bermaksud mengambil bagian aktif dalam pesta olah raga di suatu tempat atau negara seperti Asean Games, Olympiade, Thomas dan Uber Cup, Wimbeldon, Tour de Fance, F1, World Cup dan jenis olahraga lainnya. Macam cabang olahraga yang termasuk dalam jenis wisata olahraga yang bukan tergolong dalam pesta olahraga atau games, misalnya berburu, memancing, berenang, dan berbagai cabang olahraga dalam air atau diatas pegunungan.

4. Wisata Komersial
Jenis ini termasuk perjalanan untuk mengunjungi pameranpameran dan pekan raya yang bersifat komersil, seperti pameran industri, pameran dagang dan sebagainya. Pada mulanya banyak orang berpendapat bahwa hal ini tidak dapat digolongkan kedalam jenis pariwisata karena bersifat komersial, hanya dilakukan oleh orang-orang yang khusus mempunyai tujuan tertentu untuk bisnis. Tetapi kenyataannnya, dewasa ini pameranpameran atau pekan raya yang diadakan banyak sekali dikunjungi oleh orang yang hanya sekedar melihat-lihat. Maka tak jarang pameran atau pekan raya dimeriahkan dengan berbagai atraksi dan pertunjukan kesenian.

5. Wisata industry

Erat kaitannya dengan wisata komersial. Perjalanan yang dilakukan oleh rombongan pelajar atau mahasiswa, atau orang-orang biasa ke suatu kompleks atau daerah perindustrian yang banyak terdapat pabrik-pabrik atau bengkel-bengkel besar dengan maksud dan tujuan untuk mengadakan peninjauan atau penelitian. Hal ini banyak dilakukan di negara-negara yang telah maju perindustriannya dimana masyarakat berkesempatan mengadakan kunjungan ke daerah atau komplekskompleks pabrik industri berbagai jenis barang yang dihasilkan secara massal di negara tersebut.

6. Wisata Politik

Jenis ini meliputi pejalanan yang dilakukan untuk mengunjungi atau mengambil bagian secara aktif 
dalam peristiwa kegiatan politik seperti peringatan ulang tahun suatu negara/perayaan hari kemerdekaan dimana fasilitas akomodasi, sarana angkutan dan berbagai atraksi diadakan secara megah dan meriah bagi para pengunjung. Selain itu peristiwa-peristiwa penting seperti konferensi, musyawarah, kongres atau konvensi politik yang selalu disertai dengan darmawisata termasuk dalam jenis ini.

7. Wisata Konvensi

Termasuk dalam jenis wisata politik. Berbagai negara dewasa ini membangun wisata konvensi dengan menyediakan fasilitas bangunan beserta ruangan-ruangan tempat bersidang bagi para peserta konferensi, musyawarah, konvensi atau pertemuan lainnya, baik yang bersifat nasional maupun internasional. Contoh, Jakarta dengan JCC-nya (Jakarta Convention Center).

8. Wisata Sosial

Yang dimaksud dengan jenis wisata ini adalah pengorganisasian suatu perjalanan murah serta mudah untuk memberi kesempatan kepada golongan masyarakat ekonomi lemah (mereka yang tidak mampu membayar segala sesuatu yang bersifat luks) untuk mengadakan perjalanan.

9. Wisata Pertanian

Jenis wisata ini adalah pengorganisasia perjalanan yang dilakukan ke proyek-proyek pertanian, perkebunan, ladang pembibitan dan sebagainya dimana wisatawan rombongan dapat mengadakan kunjungan dan peninjauan untuk tujuan studi ataupun hanya sekedar melihat-lihat.

10. Wisata Maritim (marina) atau Bahari Jenis wisata ini banyak kaitannya dengan kegiatan di air seperti di danau, sungai, pantai, teluk atau laut lepas seperti memancing, berlayar, menyelam, berselancar dan lain-lain. Jenis wisata ini dapat juga disebut Wisata Tirta. Indonesia yang merupakan daerah kepulauan kaya akan wisata jenis ini.

11. Wisata Cagar Alam

Wisata ini banyak dikaitkan dengan kegemaran akan keindahan alam, kesegaran hawa udara di pegunungan, keajaiban hidup binatang dan marga satwa yang langka serta tumbuh-tumbuhan yang jarang terdapat di tempat lain.

12. Wisata Buru

Jenis wisata ini banyak dilakukan di negara-negara yang memiliki daerah atau hutan tempat berburu yang dibenarkan oleh pemerintah (memliki izin). Pemerintah yang bijaksana mengatur wisata buru ini demi keseimbangan hidup satwa yang diburu agar tidak punah, dengan memperhitungkan perkembangbiakannya, antara yang lahir dan yang diburu tetap seimbang.

13. Wisata Pilgrim/Wisata Religi

Jenis wisata ini banyak dikaitkan dengan agama, adat istiadat dan kepercyaan umat atau kelompok masyarakat. Bisa dilakukan perorangan atau rombongan ke tempat-tempat suci, makam-makam orang besar atau yang diagungkan. 


\section{Wisata Bulan Madu}

Yang dimaksud dengan jenis
wisata ini adalah suatu
penyelenggaraan perjalanan bagi
pasangan suami istri, pengantin baru
yang sedang berbulan madu dengan
fasilitas-fasilitas khusus dan
tersendiri demi kenikmatan
perjalanan dan kunjungan mereka.

15. Wisata petualangan

Dikenal dengan istilah adventure tourism. Jenis wisata ini dilakukan oleh mereka yang ingin melakukan petualangan atau hal-hal yang menantang, seperti memasuki hutan belantara, mendaki tebing terjal, bungy jumping, arung jeram, wisata kutub, wisata ruang angkasa dan lain sebagainya.

Selain jenis-jenis wisata tersebut, masih banyak lagi jenis wisata yang lain, tergantung kepada kondisi dan situasi perkembangan dunia kepariwisataan di suatu daerah atau negara yang ingin mengembangkan industri pariwisatanya. Hal ini tergantung pada selera atau daya kreativitas para profesional yang berkepentingan dalam industri pariwisata ini. Semakin kreatif dan banyak gagasan yang dimiliki, semakin bertambah pula bentuk dan jenis wisata yang dapat diciptakan.

\section{Wisata Bahari}

Wisata bahari adalah wisata dan lingkungan yang berdasarkan daya tarik wisata kawasan yang didominasi perairan dan kelautan. Wisata bahari adalah kegiatan untuk memikat keindahan dan keunikan daya tarik wisata alam diwilayah pesisir dan laut dekat pantai serta kegiatan rekreasi lain yang menunjang. Wisata bahari adalah kegiatan wisata yang memanfaatkan potensi alam bahari sebagai daya tarik wisata maupun wadah kegiatan wisata baik yang dilaukan diatas permukaan diwilayah laut yang tidak dapat dipisahkan dari keberadaan ekosistemnya yang kaya akan keanekaragaman jenis biota laut (R.G Soekadijo, 1996).

Wisata bahari merupakan kesan yang penuh makna bukan semata - mata memperoleh hiburan dari berbagai suguhan atraksi dan suguhn alami lingkungan pesisir dan lautan tetapi juga diharapkan wisatawan dapat berpartisipasi langsung untuk mengembangkan konservasi lingkungansekaligus pemahaman yang mendalam tentang seluk beluk ekosistem pesisir sehingga membentuk kesadaran bagaimana harus bersikap untuk melestarikan wilayah pesisir dimasa kini dan dimasa yang akan datang. Jenis wisata yang memanfaatkan wilayah pesisir dan lautan secara langsung maupun tidak langsung (R. S Damardjati, 2001).

Wisata bahari menurut Ardika (2000) adalah wisata dan lingkungan yang berdasarkan daya tarik wisata kawasan yang didominasi perairan dan kelautan. Keraf (2000) wisata bahari adalah kegiatan untuk menikmati keindahan dan keunikan daya tarik wisata alam di wilayah pesisir dan laut dekat pantai serta kegiatan rekreasi lain yang menunjang. Sarwono (2000) wisata bahari adalah kegiatan wisata yang memanfaatkan potensi alam bahari sebagai daya tarik wisata maupun wadah 
kegiatan wisata baik yang dilakukan diatas permukaan di wilayah laut yang tidak dapat dipisahkan dari keberadaan ekosistemnya yang kaya akan keanekaragaman jenis biota laut. Wisata bahari dengan kesan penuh makna bukan semata-mata memperoleh hiburan dari berbagai suguhan atraksi dan suguhan alami lingkungan pesisir dan lautan tetapi juga diharapkan wisatawan dapat berpartisipasi langsung untuk mengembangkan konservasi lingkungan sekaligus pemahaman yang mendalam tentang seluk beluk ekosistem pesisir sehingga membentuk kesadaran bagaimana harus bersikap untuk melestarikan wilayah pesisir dan dimasa kini dan masa yang akan datang.

Dalam buku Nyoman S. Pendit menjelaskan bahwa wisata bahari merupakan aktivitas wisata petualangan dilaut, memberikan informasi apa saja yang dapat dilakukan dilaut. Adapun aktivitas - aktivitasnya wisata bahari yaitu antara lain Sea Walker, Marine Walk, Ocean Walker, Odyseey Submarine, Diving, Dolphin Tour.

Pengertian wisata bahari atau tirta menurut Pendit adalah jenis pariwisata yang terkait dengan kegiatan olah raga air lebih-lebih di danau, bengawan, pantai, teluk atau lautan lepas seperti memancing, berlayar, menyelam sambil melakukan pemotretan, kompetisi selancar, mendayung dan sebagainya. Aktivitas bahari ini dapat dijumpai di daerah Bunaken Sulawesi Utara, Wakatobi, Gili Air, Gili Meno dan Gili Trawangan di Lombok, Pulau Rajaampat di Papua serta beberapa kawasan pesisir pulau Bali, termasuk salah satunya berada di pesisir pantai Sanur.

\section{Daya Tarik Wisata}

Daya Tarik Wisata sejatinya merupakan kata lain dari objek wisata namun sesuai peraturan pemerintah Indonesia tahun 2009 kata objek wisata sudah tidak relevan lagi untuk menyebutkan suatu daerah tujuan wisatawan maka digunakanlah kata “ Daya Tarik Wisata" maka untuk mengetahui apa arti dan makna dari daya tarik wisata di bawah ini adalah beberapa definisi atau pengertian mengenai Daya Tarik Wisata menurut beberapa ahli:

1. Berdasarkan Undang-Undang Republik Indonesia No. 10 tahun 2009, Daya Tarik Wisata dijelaskan sebagai segala sesuatu yang memiliki keunikan, kemudahan, dan nilai yang berupa keanekaragaman kekayaan alam, budaya, dan hasil buatan manusia yang menjadi sasaran atau kunjungan wisatawan.

2. A. Yoeti dalam bukunya "Pengantar Ilmu Pariwisata" tahun 1993 menyatakan bahwa daya tarik wisata atau "tourist attraction", istilah yang lebih sering digunakan, yaitu segala sesuatu yang menjadi daya tarik bagi orang untuk mengunjungi suatu daerah tertentu.

3. Nyoman S. Pendit dalam bukunya "Pengantar Ilmu Pariwisata" tahun 1999 mendefiniskan daya tarik wisata sebagai segala sesuatu yang menarik dan bernilai untuk dikunjungi dan dilihat.

4. Menurut undang - undang Republik Indonesia Nomor 9 tahun 1990 tentang kepariwisataan, ada dua jenis objek dan daya tarik wisata, yaitu: 
1) Objek dan daya tarik wisata ciptaan Tuhan Yang Maha Esa yang berwujud keadaan alam, flora dan fauna.

2) Objek dan daya tarik wisata hasil karya manusia yang berwujud museum, peninggalan purbakala, peninggalan sejarah, seni budaya, wisata agro, wisata tirta, wisata buru, wisata petualangan alam, taman rekreasi dan tempat hiburan.

3) Daya tarik wisata minat khusus, seperti : berburu, mendaki gunung, gua, industri dan kerajinan, tempat perbelanjaan, sungai air deras, tempat-tempat ibadah, tempat ziarah dan lain-lain.

5. Menurut Spilanne (2002), Daya tarik pariwisata adalah hal - hal yang menarik perhatian wisatawan yang dimiliki oleh suatu daerah tujuan wisata.

6. Menurut Karyono (1997) suatu daerah tujuan wisata mempunyai daya tarik di samping harus ada objek dan atraksi wisata, juga harus memiliki tiga syarat daya tarik, yaitu:

1) Ada sesuatu yang yang bisa dilihat (something to see)

2) Ada sesuatu yang dapat dikerjakan (something to do)

3) Ada sesuatu sesuatu yang bisa dibeli (something to buy)

\section{Sarana dan Prasarana pariwisata}

Dalam melakukan sebuah perjalanan wisata banyak hal yang harus diperhatikan oleh para wisatawan. Baik dari obyek wisata mana yang akan kita kunjungi, transportasi apa yang akan digunakan untuk berwisata, dan lain sebagainya. Untuk itu dalam melakukan sebuah perjalanan wisata, sarana dan prasaran pendukung dalam berwisata penting untuk diperhatikann. Dengan adanya persiapan dalam sarana dan prasarana ini maka diharapkan perjalanan wisata menjadi lebih nyaman dan menyenangkan. Adapun sarana dan prasarana dalam pariwisata antara lain:

1. Sarana Pariwisata

Ada tiga sarana yang perlu untuk di persiapkan sebelum melakukan sebuah perjalana wisata, yaitu sarana pokok pariwisata, sarana pelengkap pariwisata, dan sarana penunjang pariwisata

a. Sarana pokok pariwisata

Sarana pokok pariwisata adalah perusahaan yang hidup dan kehidupannya sangat tergantung kepada arus kedatangan orang yang melakukan perjalanan wisata, yaitu :

a) Travel Agent and Tour Operator

b) Perusahaan-perusahaan angkutan wisata

c) Hotel dan jenis akomodasi lainnya

d) Bar dan Restoran, serta rumah makan lainnya

e) Objek wisata dan atraksi wisata

Pada dasarnya, perusahaanperusahaan tersebut merupakan fasilitas minimal yang harus ada pada suatu daerah tujuan wisata, jika salah satu tidak ada maka dapat dikatakan perjalanan wisata yang dilakukan tidak 
berjalan seperti yang diharapkan. Sarana pokok parwisata ini oleh Nyoman S. Pendit disebut dengan istilah "perusahaan utama yang langsung" yang terbagi ke dalam Objek Sentra dan Subjek Sentra sebagai berikut :

a) Objek Sentra : termasuk perusahaan akomodasi, perusahaan pengangkutan/transportasi , tempat peristirahatanyang khusus bagi pengunjung yang sakit beserta kliniknya, perusahaan manufaktur (kerajinan tangan atau barang-barang kesenian), toko-toko souvenir, badan usaha yang menyajikan hiburanhiburan (EO) atau menyediakan pemandu (guide) serta penerjemah, lembaga khusus untuk mempromosikan pariwisata.

b) Subjek

Sentra : perusahaan penerbitan pariwisata yang memajukan promosi pariwisata secara umum ataupun khusus, kantor yang membiayai pariwisata (Travel Bank, Travel Credit, Social Tourism, and Youth Travel), asuransi pariwisata (seperti kecelakaan, sakit dan biaya rumah sakit saat melakukan perjalanan). b. Sarana pelengkap pariwisata Sarana pelengkap pariwisata adalah perusahaan atau tempattempat yang menyediakan fasilitas untuk rekreasi yang fungsinya tidak hanya melengkapi sarana pokok pariwisata, tetapi yang terpenting adalah untuk membuat wisatawan dapat lebih lama tinggal pada suatu daerah tujuan wisata. Sarana pelengkap pariwisata oleh Nyoman S. Pendit disebut sebagai "perusahaan pariwisata sekunder", karena tidak seluruhnya tergantung kepada kedatangan wisatawan tetapi juga diperuntukan bagi masyarakat setempat yang membutuhkannya.

Nyoman S. Pendit memberi contoh perusahaan pariwisata sekunder sebagai berikut:

a) Perusahaan yang membuat kapal khusus untuk wisatawan, seperti: cuiser, gerbong khusus bagi wisatawan, mobil atau bus khusus bagi wisatwan.

b) Toko pakaian (boutiques), toko perhiasan (jewellery), toko kelontongan dan toko foto (cuci-cetak).

c) Binatu, salon (barbershop), salon kecantikan, dan lainlain.

c. Sarana penunjang pariwisata

Sarana penunjang pariwisata adalah perusahaan yang menunjang sarana pelengkap dan sarana pokok. Selain berfungsi 
untuk membuat wisatawan lebih lama tinggal pada suatu daerah tujuan wisata, sarana penunjang pariwisata memiliki fungsi yang jauh lebih penting yaitu membuat wisatawan lebih banyak mengeluarkan atau membelanjakan uangnya di tempat yang dikunjunginya. Misalnya night club, casinos, steambaths, dan lain-lain. Adanya sarana pelengkap dan penunjang pariwisata seperti yang telah diuraikan di atas akan mendukung sarana-sarana pokok. Hal ini berarti bahwa ketiga sarana pariwisata tersebut, satu sama lainnya harus saling mengisi dan melengkapi.

2. Prasarana Pariwisata

Prof. Salah Wahab dalam bukunya Tourism Management, membagi prasarana ke dalam tiga bagian, yaitu: prasarana umum,kebutuhan masyarakat banyak, dan prasarana kepariwisataan.

a. Prasarana Umum

Prasarana yang menyangkut kebutuhan orang banyak yang pengadaannya bertujuan untuk membantu kelancaran roda perekonomian, yaitu:

a) Pembangkit tenaga listrik dan sumber energi lainnya

b) Sistem penyediaan air bersih

c) Sistem jaringan jalan raya dan jalur kereta api

d) Sistem irigasi

e) Perhubungan dan Telekumuniksi b. Kebutuhan Masyarakat Banyak Prasarana yang menyangkut kebutuhan orang banyak, seperti halnya rumah sakit, apotik, bank, kantor pos, pompa bensin, dan administrasi pemerintahan (polisi, pengadilan, badan legislatif, dan lain-lain).

c. Prasarana Kepariwisataan

a) Receptive

Tourist

Plant Segala bentuk badan usaha atau organisasi yang kegiatannya khusus untuk mempersiapkan kedatangan wisatawan pada suatu daerah tujuan wisata, yaitu:

- Perusahaan yang kegiatannya adalah merencanakan dan menyelenggarakan perjalanan bagi orang yang akan melakukan perjalanan wisata (tour operator and travel agent).

- Badan atau organisasi yang memberikan penerangan, penjelasan, promosi dan propagansa tentang suatu daerah tujuan wisata (Tourist Information Center yang terdapat di airport, terminal, pelabuhan, atau suatu resort).

b) Residental Tourist Plant Semua fasilitas yang dapat menampung kedatangan para wisatawan untuk menginap dan tinggal untuk sementara waktu di daerah tujuan wisata. Termasuk ke dalam kelompok ini adalah semua bentuk akomodasi yang diperuntukan bagi wisatawan dan juga segala bentuk rumah makan dan restoran yang ada. Misalnya hotel, motor hotel (motel), 
wisma, homestay, cottages, camping, youth hostel, serta rumah makan, restoran, self-services, cafetaria, coffee shop, grill room, bar, tavern, dan lain-lain.

c) Recreative and Sportive Plant Semua Fasilitas yang dapat digunakan untuk tujuan rekreasi dan olah raga. Termasuk ke dalam kelompok ini adalah fasilitas untuk bermain golf, kolam renang, boating, surfing, fishing, tennis court, dan fasilitas lainnya.

\section{PEMBAHASAN}

\section{Sejarah Pantai Tanjung Benoa}

Tanjung Benoa adalah sebuah kelurahan yang berada di sebelah tenggara pulau Bali. Termasuk dalam kecamatan Kuta Selatan, Kabupaten Badung. Pantai Tanjung Benoa Bali, sangat terkenal dengan aktivitas rekreasi air atau wisata bahari dan sering disebut dengan nama, Tanjung Benoa watersport. Tempat wisata Tanjung Benoa, sangat berdekatan dengan salah satu tempat wisata di Bali yang sering digunakan sebagai tempat konfrensi, yaitu Nusa Dua.

"Sejarah Tanjung Benoa, kampung nelayan menjadi kawasan wisata mewah, pusat wisata bahari, dikenal dengan water sport Tanjung Benoa.

Sebelum berkembang menjadi kawasan wisata di Bali, tempat terdapatnya hotel-hotel mewah dan restoran. Sejarah Tanjung Benoa merupakan perkampungan nelayan. Sebagian besar penduduk di Tanjung Benoa, berprofessi sebagai nelayan sebelum berkembangnya pariwisata di daerah ini. Perkembangan daerah ini sangat signifikan dari awalnya kampung nelayan, menjadi kawasan wisata tempat dari hotel-hotel mewah, spa, tempat shoping untuk oleh-oleh khas Bali dan restoran berstandard international. Kawasan wisata ini, memang sangat cocok untuk aktivitas wisata bahari. Karena memiliki air laut yang tenang dan panorama bawah laut yang tidak kalah dengan pantai-pantai di Bali yang lain. Sebagian besar peminat wisata bahari adalah wisatawan yang berlibur bersama keluarga.

Kawasan wisata Tanjung Benoa, memiliki letak geografis yang unik. Diapit oleh dua laut dan kedua sisi dari pantai memiliki pasir putih. Sejarah Tanjung Benoa, sekitar tahun 1546, pantai Tanjung Benoa adalah sebuah pelabuhan kecil. Yang di gunakan oleh pedagang dari Cina, untuk berlabuh dan menjual barang dagangan mereka seperti keramik. Selain menjual, pedagang Cina juga membeli barang dagangan penduduk asli Bali. Pertukaran barang dagangan di pelabuhan inilah, yang membuat beberapa dari pedagang Cina menetap di Tanjung Benoa. Dengan menepatnya penduduk Cina di Tanjung Benoa, membuat sebuah keunikan di tempat wisata ini, yaitu terdapatnya klenteng atau Vihara yang lumayan besar. Nama vihara yang ada di Tanjung Benoa adalah Vihara Caow Eng Bio. Selain vihara, anda juga dapat melihat candi Hindhu seperti Pura Dalem 
Tengkulung Benoa Tanjung dan Pura Segara.

Sebelum berkembang menjadi tempat pariwisata di Bali. Daerah ini adalah kampung nelayan, yang sebagian besar penduduk lokal untuk mencari mata pencaharian dengan menjadi nelayan. Semenjak tahun 1980, kawasan terdekat dari Tanjung Benoa yaitu Nusa Dua, di bangun kawasan wisata mewah yang bernama BTDC. Di kawasan BTDC Nusa Dua, berdiri hotel-hotel mewah yang hampir sebagian besar hotel bintang lima. Dengan perkembangan signifikan dari BTDC Nusa Dua, berhimbas terhadap daerah Tanjung Benoa. Tentunya dengan kelebihan pantai pasir putih, air laut yang tenang, pohon palem dan kelapa di daerah sekitar pantai. Membuat pantai Tanjung Benoa tidak ketinggalan dari Nusa Dua dalam perkembangan pariwisata di pulau Bali. Pemerintah daerah pulau Bali, telah menetapkan kawasan Tanjung Benoa menjadi pusat dari wisata bahari di Bali. Pemerintah daerah Bali juga membuat tempat penangkaran Penyu hijau, yang termasuk kategori satwa langka dan dilindungi. Tempat penangkaran ini, lebih dikenal dengan nama pulau Penyu. Lihat disini untuk lebih detail tentang pulau Penyu Tanjung Benoa.

\section{Faktor-faktor Pengembangan Pariwisata Bahari di Pantai Tanjung Benoa}

Pantai Tanjung Benoa yang dulu merupakan sebuah kampung nelayan kini menjadi sebuah obyek wisaya yang dikenal oleh seluruh dunia karena daya tarik dan keunikan yang ditawarkan. Dalam perkembangannya didunia pariwisata pantai tanjung benoa sudah mengalami banyak perkembangan, sehingga dapat dikenal seperti sekarang ini. Wisata ait Tanjung Benoa semakin baik yang ditandai dengan bertambahnya jumlah pengembangan wahana dan tingginya kunjungan setiap tahunnya. Perkembangan yang dilakukan di kampung nelayan ini unuk menarik wisatawan datang berkunjung yaitu dengan membuka wahana water sport.

Adapun faktor pendorong pengembangan wahana water sport di pantai tanjung benoa, yaitu:

1. Keindahan pantai dengan pasir putih yang lembut

Hal Pertama yang mampu melirikan mata secara spontan ialah dengan keindahan yang ada di pantainya. Hamparan pasir putih yang lembut beserta dengan airnya yang jernih berwarna biru tentunya menjadi sebuah penenang bagi pikiran yang penuh dengan kepenatan. Bukan hanya itu saja kita juga bisa berjemur dikawasan panti tanjung benoa sambil bersantai melihat pemandangan yang tidak ada ujungnya di depan mata. Oleh karena itu, penting bagi para pengelola Pantai Tanjung Benoa untuk tetap menjaga keindahan dan keasrian dari pantai. Dengan aksesnya yang mudah, pantai tanjung benoa sendiri juga memiliki banyak sekali fasilitas yang bisa membuat liburan semakin nyaman. Mulai dari restoran, resort, toko seni hingga toko untuk peralatan olahraga air yang ada dipantai ini.

2. Gelombang air lautnya yang tenang

Selain menjadi pantai yang terkenal hingga mancanegara yang 
menawarkan banyak keindahan. Gelombang air lautnya yang tenang menjadi salah satu pengembangan wahana Watersport di pantai tanjung benoa. Seperti kita ketahui bahwa pantai Tanjung Benoa merupakan kawasan wisata pantai yang merupakan surga bagi wahanan permainan air di Bali yang menjadi favorit bagi para wisatawan .

Adapun wahana-wahana air yang terdapat di pantai tanjung benoa terdiri dari beberapa wahana antara lain:

\section{a. Jet Sky}

Jet Sky adalah salah satu water sports dengan menaiki jets air atau sepeda motor air pada kecepatan tinggi.

b. Banana Boat

Banana Boat adalah water sports dengan menggunakan perahu karet berbentuk pisang yang dinaiki maksimum oleh 6 orang. Kemudian sebuah speed boat yang menarik ketengah laut.

c. Parasailling

Parasailling yaitu olahraga payung yang ukurannya disesuaikan dengan berat pemain akan ditarik oleh sebuah bspeed boat.

d. Scuba Diving

Scuba Diving adalah wisata air menyelam sampai kebawah laut untuk menikmati indahnya alam terumbu karang dan ikan.

e. Snorkeling

Snorkeling adalah kegiatan berenang atau menyelam menggunakan peralatan berupa masker selam dan snorkel. Selain itu penyelam sering menggunakan alat bantu gerak berupa kaki katak (sirip selam) untuk menambah daya dorong pada kaki.

f. Pulau Penyu pulau penyu ini adalah lokasi penangkaran berbagai spesies penyu yang mulai langka. Untuk mencapai pulau ini, dapat menggunakan perahu yang beralas kaca sambil menikmati keindahan bawah lautnya. Tidak hanya sekedar melihat berbagai macam spesien penyu tetapi disana kita juga dapat melihat proses pengembangbiakan penyu yaitu cara penetasan penyu.

g. Bentangan pantainya yang lebar Keindahan pantai Tanjung Benoa Bali, terdapat pada pasir pantai yang berwarna putih dengan bentangan pantai yang sangat panjang. Karena area Tanjung Benoa adalah kawasan semenanjung, maka pantai Tanjung Benoa Bali memiliki dua sisi. Satu sisi pantai menghadap ke sisi barat dan sisi pantai yang menghadap ke timur. Karena berada di kawasan semenanjung membuat gelombang ombak pantai Tanjung Benoa Nusa Dua sangat tenang.

\section{Cara Meningkatkan Daya Tarik}

Pariwisata Bahari di Pantai Tanjung

\section{Benoa}

Dalam usaha untuk meningkatkan daya tarik pariwisata yang ada di Pantai Tanjung Benoa, diharapkan dukungan dari semua pihak khususnya komponen pariwisata Tanjung Benoa agar tetap menjaga kelestariannya. Pertumbuhan pariwisata tersebut mampu 
meningkatkan taraf hidup masyarakat sekaligus meningkatkan kualitas pendidikan anak - anak hingga ke perguruan tinggi. Selain itu, penyumbang sumber pendapat daerah Kabupaten Badung yang digunakan untuk membangun infrastuktur pelayanan umum, termasuk tempat ibadah umat Hindu sebagai upaya melestarikan budaya Bali. Hal itu penting karena Bali membutuhkan sumber finansial yang kuat untuk menopang berbagai program mempertahankan dan melestarikan budaya yang beragam yang mampu menjadi daya tarik turis untuk datang. Sebelum sektor pariwisata berkembang di kawasan Tanjung Benoa, masyarakat setempat mempunyai mata pencarian sebagai nelayan penangkap ikan, namun sekarang berubah total sebagai pengangkut wisatawan dalam menikmati berbagai atraksi wisata di laut. Perubahan tersebut terjadi 180 derajat sehingga memperikan dampak yang positif terhadap tingkat kesejahteraan masyarakat.

Selain keindahan pantai dan juga wahana air yag ditawarkan, terdapat juga klenteng dan pura yang menjadi daya tarik Tanjung Benoa.

\section{Klenteng Cao Eng Bio}

Bukan hanya sekedar keindahan alamnya saja, namun ketika berada di kawasan tanjung benoa kita juga bisa merasakan budayanya yang beragam. Salah satu buktinya ialah denagn berdirinya klenteng paling tua yang ada di bali. Di dalam kawasan klenteng ini kita bisa melihat beragam budaya tiongkok yang mampu bertahan. Klenteng ini pertama kali dibangun oleh para pedagang dari tiogkok yang datang kebali pada zaman dulu. Klenteng inipun sangat mudah untuk ditemukan atau bisa dibilang juga mudah untuk melihatnya. Mulai dari dinding merahnya yang sangat cerah hingga bentuk infrastrukturnya yang unik. Klenteng yang berada di Jalan Segara Ening ini memang sering sekali menjadi tempat tujuan para wisatawan yang ingin melihat keanekaragaman budaya yang ada di tanjung benoa.

2. Pura Dalem Ning Lan Taman Beji

Pura ini merupakan salah satu pura yang ada dikawasan tanjung benoa. Karena memang kita dapat melihat beragam keunikan serta keindahan dalam kawasan pura ini. Pura yang memiliki infrastruktur yang unik ini memang menjadi sebuah daya tarik tersendiri terhadap pariwisata yang ada di tanjung benoa. Tak heran apabila pura ini pun menjadi magnet bagi para wisatawan baik dari dalam maupun luar negeri. Sebagian besar bahan material untuk membangun Pura Dalem Ning Lan Taman Beji, terbuat dari batu putih, serta pintu gerbang terbuat dari kayu dengan ukiran yang sangat indah. Lokasinya pun tidak terlalu jauh dari klenteng caow eng bio, tentunya pura ini bisa menjadi destinasi yang tepat setelah puas berada di kawasan klenteng.

Berbagai upaya dan terobosan dilakukan agar wisatawan mancanegara tetap tertarik berkunjung ke Pantai Tanjung Benoa serta menemukan nuansa dan hal-hal baru, meskipun sudah berulang kali 
berlibur ke Pantai Tanjung Benoa. Salah satu upaya yang pernah dilakukan oleh Pemkab Badung dalam upaya meningkatkan daya tarik Pantai Tanjung Benoa yaitu dengan menggelar Festival Bahari.

Festival bahari dalam kemasan yang unik dan menarik itu memiliki sedikitnya sepuluh jenis kegiatan yang mampu menjadi daya tarik tersendiri bagi wisatawan mancanegara maupun wisatawan nusantara. Kegiatan itu antara lain menyangkut wisata kuliner Nusantara, pementasan sendratari, dan aneka jenis kesenian tradisional di Pulau Dewata, dan juga atraksiatraksi wisata yang ada di Pantai Tanjung Benoa. Kegiatan tersebut akan dimeriahkan dengan pementasan tarian massal serta pemilihan putra-putri bahari maupun pemilihan "King and Queen bagi wisatawan mancanegara. Berbagai kegiatan festival bahari diisi juga dengan berbagai kegiatan, termasuk diantaranya memancing ikan dan bermai papan selancar (surfing) selain itu juga digelar International Dragon Boat Federation (IDBF) yang melibatkan perwakilan dari sejumlah negara.

\section{Sarana dan Prasarana}

Dalam melakukan perjalanan wisata, sarana dan prasarana sangat penting untuk di perhatikan.Termasuk Pemeliharaan dan keamanan sarana dan prasarana tersebut dimana, dengan adanya sarana dan prasarana yang terjamin di harapkan mampu memberi rasa nyaman dan aman serta peningkatan kepuasan bagi wisatawan.

Adapun sarana dan prasaran yang terdapat di pantai tanjung benoa diantaranya :

1. Sarana dan Prasarana Wisata

a. Transportasi

Saat berlibur atau berkunjung ke pantai tanjung benoa biasanya wisatawan sanagat tertarik untuk mengunjunggi pulau penyu. Alat transportasi yang digunakan untuk menuju ke Pulau Penyu, yaitu Glass Bottom Boat (perahu dengan lantai kaca) . Demi keamanan glass bottom boat dilengkapi dengan pelampung (life vest),yang berfungi untuk mengapungkan wisatawan diatas air. Lantai perahu terbuat dari kaca bening yang tembus pandang sehingga wisatawan juga dapat menikmati pemandangan bawah laut yang mengagumkan selama perjalanan menuju Pulau Penyu Tanjung Benoa.Sebelum sampai ke Pulau Penyu, pengemudi perahu akan mengantar wisatawan ke lokasi perairan yang banyak terdapat ikan. Untuk menaiki glass bottom boat, wisatawan akan dikenai biaya sewa Rp 1 juta untuk 1 boat dengan kapasitas 10 orang.

b. Biro Perjalanan Wisata

Bagi wisatawan luar yang berkunjung ke pantai tanjung benoa, ada baiknya ditemani pemandu yang paham tentang rute dan obyek wisata, tempat makan, dan detail wisata disana 
karena akan sangat membantu dalam berinteraksi dan kelancaran selama berwisata.

2. Sarana dan prasarana wahana

a. Jet Sky

Jetski adalah permainan air yang menggunakan boat bertenaga motor jet. menggunakan jet air berkecepatan tinggi dan ditambah benturan dengan ombak pantai. permainan Jetski Tanjung Benoa yang juga dikenal dengan nama Waverunner tidak bisa dikendarai sendiri, harus didampingi oleh instruktur, mengingat di pantai Tanjung Benoa Bali banyak terdapat perahu dan aktivitas watersport lainnya, sehingga tabrakan bisa dihindari. sebelum memainkan aktifitas ini wisatawan diharuskan menggunakan life jacket atau pelampung. Ini adalah saranana dan standar keamanan yang wajib dipatuhi.

b. Banana Boat

Banana Boat adalah water sports dengan menggunakan perahu karet berbentuk pisang. Sarana dan prasarana yang digunakan pada wahana permainan banana boat di Tanjung Benoa sudah sesuai standar keamanan. Seperti jaket pelampung, speed boat dan banana boat itu sendiri. Selain itu, setiap peserta yang menaiki perahu banana boat, harus ditemani pemandu yang sudah terlatih dan berpengalaman, sehingga keamanan dan kenyamanan wisatawan sangat terjaga dalam aktivitas banana boat .Perahu karet untuk aktivitas banana boat Tanjung Benoa terbuat dari karet yang tebal dan ringan, sehingga mudah ditarik dan diarahkan oleh speed boat. Jarak antara tali pengikat perahu dengan speed boat sekitar lima meter. Panjang tali diatur untuk memudahkan komunikasi antara pemandu yang duduk di perahu dengan sopir speedboat.

c. Parasailling

Parasailling yaitu olahraga payung yang ditarik dengan speedboat. Sebelum mencoba permainan parasailing wisatawan akan diberi pengarahan oleh pemandu. Mulai dari pengenalan saranan permainan parasailing yang digunakan, posisi berdiri sebelum terbang, posisi pada saat di udara, dan teknik sebelum mendarat.. sarana yang digunakan dalam wahana permainan parasailing, sudah memenuhi standar keamanan internasional.. Selain payung parasut, peserta wahana juga menggunakan jaket pelampung, untuk menjaga peserta agar tetap terapung, jika payung parasutnya jatuh di laut.

d. Scuba Diving

Scuba Diving adalah wisata air menyelam sampai kebawah laut untuk menikmati indahnya alam terumbu karang dan ikan. Proses aktivitas scuba diving Bali 
Tanjung Benoa, diawali dengan perkenalan sarana dan prasaraana menyelam seperti Masker, fins (sepatu katak ), Boot, Bcd (bouyancy compensator device), Regulator, Tank (tabung oksigen),Wetsuit (baju selam),Weight belt (sabuk pemberat) dan peralatan lainnya yang sudah memenuhi standar keamaan yang terjaga. Kemudian akan diperkenalkan bagaimana cara berenang, serta teknik pernapasan di dalam laut. Hal itu penting dilakukan untuk menjaga keamanan wisatawan saat menyelam.

e. Snorkeling

Snorkeling adalah kegiatan berenang atau menyelam menggunakan peralatan selam. Sarana dan prasarana yang di gunakan tidak jauh berbrda dengan scuba diving. Sarana Tersebut berupa masker selam dan snorkel. Selain itu penyelam sering menggunakan alat bantu gerak berupa kaki katak (sirip selam) untuk menambah daya dorong pada kaki.

Sarana dan Prasarana yang ada di Wisata dan Wahana Pantai Tanjung benoa sanagat penting untuk dijaga kemanannya, terlebih lagi sarana dan prasarana yang adigunakan paada setiap wahana. Karena wahana merupakan salah satu faktor daya tarik wisatawan. Hal - hal yang mugkin terjadi apabila sarana dan prasaran wisata dan wahana pantai tanjung benoa tidak terjaaga keamanannya yaitu :
1. Daya Tarik Wisatawan menurun

2. minimnya kunjungan dan loyalitas wisatawan. ini di karenakan kepuasaan dan kenyamanan wisatawan terganggu

3. Kemungkinan tingkat kecelakan tinggi.

Dampak yang ditimbulkan dari hal tersebut yaitu pendapatan masyarakat daerah menurun karena keinginan wisatwan untuk berkunjung kembali dan keinginan untuk merefrensikan wisata tersebut kepada wisatawan lain sanagat minim. Sarana dan prasarana yang kurang memadai pun menyebabkan wisatawan berpindah ke destinasi wisata lainnya.

\section{SIMPULAN DAN SARAN}

\section{Simpulan}

Berdasarkan pembahasan diatas, maka diperoleh simpulan bahwa obyek wisata tanjung benoa memiliki potensi yang sangat besar untuk dikembangkan sebagai pusat wisata air dan rekreasi. Pengelolaan yang tepat berkesinambungan dapat memberikan dampak yang positif bagi pengembangan daya tarik, di pantai tanjung benoa. Partisipasi pelaku pariwisata juga sangat penting bagi pengembanagan daya tarik yang ada disana., dimana para pelaku pariwisata diharapkan ikut serta dalam memjaga kebersihan pantai tanjung benoa, menjaga kelestarian penyunya,serta memperhatikan sarana dan prasarana pendukung yang menjamin keamanan dan keselamatan guna meningkatkan kepuasan wisatawan diobyek wisata tanjung benoa. 


\section{Saran}

Dengan adanya potensi sumber daya alam yang baik, diharapkan pemerintah daerah berperan aktif dalam pengelolaan serta memasarkan potensi pada pulau tersebut. Hal utama yang dapat dilakukan adalah membangun dan mengoptimalkan sarana dan prasarana penunjang kegiatan wisata bahari pantai tanjung benoa serta menggandeng pihak swasta yang ingin mengembangkan daerah tersebut menjadi Objek Daerah Tujuan Wisata (ODTW) yang memiliki konsep ekowisata.

\section{DAFTAR PUSTAKA}

A. Hari Karyono. 1997. Kepariwisataan. Jakarta. Grasindo

Damardjati. R.S. 2001. Istilah-istilah Dunia Pariwisata. Jakarta. PT Pradnya Paramita.

J. Spillane DR, 2002, Ekonomi Pariwisata Sejarah dan Prospeknya. Yogyakarta. Kanisius

Keraf. 2000. Dimensi Budaya, Ekologi

Pesisir dan Laut dalam Pembangunan Wisata Bahari. Naskah Seminar. Denpasar. Kajian Budaya Universitas Udayana.

Kusumaatmadja, Sarwono, 2000, Wisata

Bahari Sebagai Andalan

Pembangunan Nasional.

Denpasar. Universitas

Udayana.
Pendit, I Nyoman, S. 1999. Ilmu Pariwisata Sebuah Pengantar. Jakarta. PT Pradya Paramita.

Republik Indonesia. 2009. UndangUndang Nomor 10 tahun 2009 tentang Kepariwisataan. Lembaran Negara RI Tahun 2009. Sekretariat Negara. Jakarta.

R. G Soekadijo. 1996. Anatomi Pariwisata. Jakarta: PT Gramedia Pustaka Utama.

Wahab, Salah.

1975. Tourism

Management. Tourism

International Press. London

www.nusabali.com/berita/23012/kunjun gan-wisatawan-ke-tanjungbenoa-

meningkat

Yoeti, Oka A. 1993. Pengantar Ilmu Pariwisata. Bandung. Angkasa

Ni Luh Kardini 